\title{
Terrorism and Culture: Macbeth, 9/11 and the Gunpowder Plot
}

\section{Graham Holderness}

\section{(2) OpenEdition \\ Journals}

Édition électronique

URL : https://journals.openedition.org/shakespeare/4111

DOI : 10.4000/shakespeare.4111

ISSN : 2271-6424

Éditeur

Société Française Shakespeare

\section{Référence électronique}

Graham Holderness, «Terrorism and Culture: Macbeth, 9/11 and the Gunpowder Plot », Actes des congrès de la Société française Shakespeare [En ligne], 36 | 2018, mis en ligne le 04 avril 2018, consulté le 25 août 2021. URL : http://journals.openedition.org/shakespeare/4111 ; DOI : https://doi.org/ $10.4000 /$ shakespeare.4111

Ce document a été généré automatiquement le 25 août 2021.

(c) SFS 


\title{
Terrorism and Culture: Macbeth, 9/11 and the Gunpowder Plot
}

\author{
Graham Holderness
}

1 Robert Appelbaum defines terrorism as "violence undertaken to advance a political agenda". ${ }^{1}$ Without the latter, violence is just violence, and doesn't qualify as terrorism. Terrorism always "sends a message", is invariably "violence that speaks and ... in speaking, has the power of changing power". ${ }^{2}$ In connecting terrorist violence with the agenda it purports to serve (or as we used to say, the end with the means) Appelbaum also facilitates their disengagement, by implying that the political purpose cannot be reduced to its chosen method (the end might justify the means). If terrorism is "the strategic use of violence to advance a political agenda", ${ }^{3}$ then what Martha Crenshaw calls its "tactical aspect" ${ }^{4}$ cannot simply be identified with its parent agenda, and the political cause that invests in terrorist violence cannot be invalidated by reference to the terrorist violence alone. Any analysis of terrorism that seeks to ignore or minimise its constitutive political "agenda" is likely to misinterpret its significance. If we respond to terrorism as meaningless violence, we are simply refusing to listen to its 'message'. If we view terrorism solely from the point of view of its victims, we are more likely to perceive it as random and arbitrary, and again fail to comprehend its communication. If we regard a particular act of terrorism as something literally unspeakable, unthinkable, impossible to comprehend - as has been said of both the Gunpowder Plot and 9/115 - then we will never understand, either historically or politically, what terrorism is all about.

2 The example Appelbaum provides in his essay "Shakespeare and Terrorism" is the murder of David Riccio by Darnley, Ruthven and Moray in $1566 .{ }^{6}$ Clearly an act of terrorism conducted by Protestant men, designed to intimidate Queen Mary herself and her Catholic supporters, the savage act of butchery was not (according to Appelbaum) without political meaning. In George Buchanan's History of Scotland (1690) Riccio's murder is narrated as "a symbolic assertion of republican values". The historian attributes to the killers a "political program" very similar to his own republican theory of sovereignty. In assassinating the Queen's favourite, they were sending "a message 
about governance". ${ }^{7}$ The message was in essence that the Queen was guilty of both tyranny and nepotism, where she ought to have ruled under the law and with the consent of the nobility; and its intended audience included the Queen herself, her allies and the nation at large. For both Buchanan and Appelbaum "the communicative nature of the violence"s is more important than the nature of the violence itself. To qualify as terrorism - as the murder of Riccio clearly does - the violence must speak for itself. The Protestant nobles could just have communicated their political programme to Mary through more conventional channels; but they chose instead to demonstrate both its necessity, and their power to perform it, in the form of an object-lesson - by stabbing her favourite to death in her presence.

Riccio's murder did not change relations of power in the intended way, as the subsequent execution of the conspirators and the later murder of Darnley abundantly demonstrate. But Appelbaum's point is not about whether terrorism is or is not successful, ${ }^{9}$ but about what it has to say, the language its violence speaks. The murder was "a case of violence meant to send a message with the power of changing power". ${ }^{10}$ The Gunpowder Plot also failed in its objective of "modifying power relations", ${ }_{11}^{11}$ "but it nonetheless had a very clear political purpose. That manifest and easily intelligible "political agenda" was nonetheless systematically denied by the Stuart state and its apologists. The Plot was an attempted act of unprecedented cruelty and evil - an "offense that no man can express" (Edward Coke) ${ }^{12}$; "an hyperdiabolical devilishness" (William Barlowe). ${ }^{13}$ Appelbaum summarises the official response to the Plot as a programme of "depoliticization": there was no reason for it, according to the state, other than envy and evil; it had nothing to say about power or justice. It testified only, in King James's own words, quoted from the 2nd Epistle to the Thessalonians, to "the mystery of iniquity". ${ }^{14}$

In his judicious discussion of my essay "Shakespeare and Terror" 15 , which links Macbeth, the Gunpowder Plot and 9/11, Appelbaum sees my argument as a retrospective collusion with the Stuart state, whose agents insisted that the intended violence of the Gunpowder Plot exhausted its meaning in violence, and had nothing else to say. He applauds my interpretation of Macbeth as an embodiment of the "terrorist imagination'; agrees that the the play is a "total response to the idea of the Plot"; and accepts the "provocative statement" that Macbeth "is himself the Gunpowder Plot", ${ }^{16}$ even supplementing this assertion with another, contemporary parallel: "Macbeth is jihad". ${ }^{17}$ But he observes that by claiming Macbeth has no political agenda - "There is in Macbeth no notion of effecting political change, destroying tyranny, bringing about an improved state of affairs" 18 - I am concurring with Barlowe, Coke and James I that "the Plot was without any purposes beyond vaulting ambition". ${ }^{19}$ And in denying it political recognition, I am also disqualifying it from Appelbaum's definition of terrorism.

In Terrorism Before the Letter, Appelbaum seems to some degree to concur with what he understands me to be saying of the Gunpowder Plot: "[i]n retrospect it may seem that King James was certainly right, that the $9 / 11$ of early modern England would have been a catastrophe beyond imagination [...]." ${ }^{20}$ But there is a qualification:

[B]ut that is because Coke (and we along with him) look at what might have been

from the side of the intended victims ... we are happy to resist the meaning of the intended violence. But from the opposite point of view, if the Plot had succeeded, who knows what the climate of discourse would have been in the end? Who knows how its message would have been disambiguated? ${ }^{21}$ 
6$$
\text { complete re-write of its "founding violence" in the course of forming a state that would }
$$
complete re-write of its "founding violence" in the course of forming a state that would perhaps have been no worse than the Jacobean one. To align ourselves with the view that both the Gunpowder Plot and 9/11 represent forms of terrorist violence that remain (rhetorically of course), unspeakable, unprecedented, immeasurable ("no man can express it, no example pattern it, no measure contain it") ${ }^{22}$ is in Appelbaum's view to court misunderstanding. We should also consider, he argues, what was meant by the intended or successful perpetrator, look at the events from both sides, disambiguate the speech of violence so we can hear its political voice.

7 Now of course terrorism speaks, means something, communicates a message. It is "propaganda by deed", or it is not terrorism. The perpetrators of the failed Gunpowder Plot were absolutely explicit about their political programme and the symbolism of the atrocity itself: they spoke to their captors, extensively and explicitly. Fawkes explained to the Council that they had intended to "purge the kingdom of perfidious heresies"; and chose to destroy Parliament because it was there that true religion "had been universally suppressed". The plotters even set up their own equivalent of a video testament, having a ship at the ready to cross to Europe and "give news of the deed to the rulers of Christendom". They were already planning for a different future.

8 Here the parallel with 9/11 - an act of "performance violence", aimed at targets of huge "symbolic significance" (as Jurgensmeyer ${ }^{23}$ puts it) - is clear. The terrorists of 9/11 attacked (or tried to attack) the same primary symbols of economic, political and military power (the WTC, Pentagon, possibly Congress), and Bin Laden explained exactly why and what for in his October 2001 videotape: America was the "oppressor", the murderer of Muslims, and should immediately withdraw from "the land of Muhammed". You'd have to be deaf not to hear messages like these.

So does that condition of "unspeakability" arise from a perspective which simply sides with the victims of terrorism, as suggested by Peter C. Herman: "to those on the receiving end, terrorism is unspeakable"?24 Why would anyone do this to me? What have I done to deserve this? I can't understand it. Here again a common rhetoric connects the Plot with 9/11. 'A production without a match', said Barlow: "a treason without parallel". 25 "Sine nomine", said Edward Coke ${ }^{26}$ (suggesting Shakespeare's "a deed without a name"). And King James couldn't find words to express it: "the like was never either heard or read": "Vox facibus haeret" [my voice sticks in my throat]'. ${ }^{27}$ "'Something' that we do not yet really know how to identify, determine, recognize, or analyse", was how Derrida described 9/11, ${ }^{28}$ a "limit event", according to Kristiaan Versluys, "that defeats the normal process of meaning making". ${ }^{29}$

10 And so as academics, as intellectuals, we insist that the unspeakable be given a voice, we call for a "long, wide view of terrorist violence", ${ }^{30}$ a "more nuanced approach". ${ }^{31}$ One of the tactics of this demand is to invoke the dogma of moral equivalence: there is little if any difference between the terrorist and those he attacks. If we look beyond the explosion and our fear, and decode its message, we might hear something that is not unreasonable. After all, are we not as bad as they are? "The threatened violence of the Gunpowder Plot" says Peter Herman, "[...] was an integral but occluded aspect of the Jacobean state"; while "a more complex sense of [9/11] recognises American complicity and 'the brutality of enhanced interrogation"'.32 In both cases effect is neatly elided with cause, reprisal cited as originating violence. Maybe I hit you first, but you started 
it. Terry Eagleton writes of "the ineradicable terror that lies at the heart of social existence". ${ }^{33}$

11 The doctrine of moral equivalence derives ultimately from earlier post-structuralist work on Shakespeare. Alan Sinfield for example stated that in Macbeth, and in the play's critical reception, a clear distinction is visible between "the violence the state considers legitimate and that it does not". ${ }^{34}$ According to this ideological perspective "violence is good ... when it is in the service of the prevailing dispositions of power; when it disrupts them, it is evil". ${ }^{35}$ This 'qualitative' distinction between kinds of violence otherwise indistinguishable seems 'natural' only because we are ideologically trained not to think of state violence as violence at all. This distinction parallels Zizek's contrast between "subjective" and "systemic" violence. We notice the former, "acts of crime and terror", and are blind to the latter, which provides our standard of a normal "non-violent zero": "Systemic violence is something like the 'dark matter' of physics, that counterpart to an all-too-visible subjective violence". ${ }^{36}$ Sinfield's argument is that the play can be read either conventionally - as implicitly endorsing state violence, and condemning the violence of disruption and insurrection; or oppositionally - as equating the two. The play contains both possibilities, and the 'qualitative' difference lies in the chosen strategy of reading.

Frances Barker's reading of Macbeth in The Culture of Violence also distinguishes between illegitimate and legitimate violence, between "the transgressive deed" and "violence in the name of the restitution of legitimacy". ${ }^{37}$ He concedes that these forms of violence are remarkably similar in the play, even twinned with one another, as the play invests its poetry both in authority and in the energies that seek to overthrow it. Barker concludes however that ultimately Macbeth "exists precisely to warn against such an alteration in the sovereign order". ${ }^{38}$ The play shares in the tendency of culture to collude with violence.

When Macbeth is described as confronting the rebel Cawdor on the battle-field with "self-comparisons" (1.2.56), the audience is made aware of likeness as well as difference. This, together with Macbeth's rapid alternation of titles, indicates that identity here is not fixed, but dispersed among patterns of similarity. The violent killing of Macdonald thus prepares us for the murder of Duncan, and ultimately for Macbeth's own death, which parallels both his initial repression of rebellion, and his act of regicide. Although Duncan's sacred kingship can produce an ideological language of organicism, social totality, kinship and family, the play makes absolutely explicit the bloody violence that underpins it:

$[\mathrm{H}] \mathrm{e}$ faced the slave

Which ne'er shook hands, nor bade farewell to him,

Till he unseamed him from the nave to th'chaps

And fixed his head upon our battlements. (1.2.21-23) ${ }^{39}$

Royal authority, whether it be gracious Duncan's or canny Malcolm's, requires as its legitimising totem the severed head of a defeated enemy, Macdonald or Macbeth. Thus the text reveals the unmistakable similarity between "subjective" and "systemic" violence, and simultaneously represents and demystifies state power. ${ }^{40}$ For Barker, Macbeth is "the tragedy that comes closest to dramatising the monarch in presence", but also comes closest to "dramatising, only just in the wings, the violent overthrow of that same sovereignty". ${ }^{41}$ The play is able "both to confirm the ideology of kingship in an unassailable positivity, and also to heighten and intensify the assault on that sovereignty which inheres in the act of political murder and 'social' violation at the 
centre of the play". ${ }^{42}$ Ultimately, however, for Barker Macbeth presents "violence in the name of restitution of legitimacy" as "wholly to be sanctioned", while the "transgressive deed" of dissident violence is " punished savagely" ${ }^{43}$ Thus the play ends with "a crushing victory for reparation". ${ }^{44}$

These readings stand as typical New Historicist and cultural materialist takes on Macbeth. The play presents both state violence and terrorist violence, but colludes with state violence in a tribute to legitimacy. Sinfield and Barker both see the play in this way, as Sinfield admits that it has to be read "against the grain" to produce a radical reading. Here then, where "power is constituted through theatrical celebrations of royal glory and theatrical violence visited upon enemies of that glory", Shakespearean tragedy is "one of power's essential modes". ${ }^{45}$ Here we see the "family resemblance between authority and its Other" ${ }^{46}$ The context of the play could hardly be more conducive to this collusion of culture with power if, as some scholars suggest, Macbeth was played before James I at Hampton Court in August 1606, possibly before the first such assembly of state officials gathered since the discovery of Gunpowder Plot. Jonathan Goldberg notes that the play begins and ends with severed heads; ${ }^{47}$ and Leonard Tennenhouse suggests that those severed heads represent a historical reversal of fortune parallel to November 1605. The assassin's head is served up to the king in an inversion of terror that offers violence to the sovereign as a gift: "The play's tribute to James comes as Shakespeare signals the reversal of Macbeth's reversal [...] by having Macduff hold up the severed head of a tyrant." 48

Just as at the beginning Macbeth plays the hangman in enacting a ritual disembowelling and decapitation of Macdonald, so at the end Macduff echoes the executioner's cry: "Behold where stands/Th'usurper's cursed head" (5.9.21-2). Both killings point unmistakably towards Tyburn, and the ritual slaughtering of the Gunpowder Plotters and other Catholics. The answer to terror is war on terror: "blood will have blood" (3.4.122). But because in a war on terror the innocent suffer along with the guilty, such violence shows, in Richard Wilson's words, "the history of terror humanist culture shares with the tyranny it opposes". ${ }^{49}$

Scholars argue about the date of Macbeth, and whether or not the single Folio text we have may incorporate several different versions of the play. But there is general agreement that there is a close relationship between the play and the Gunpowder Plot:

If th'assassination

Could trammel up the consequence and catch

With his surcease, success, that but this blow

Might be the be-all and the end-all - here,

But here, upon this bank and shoal of time,

We'd jump the life to come. (1.7.2-7)

"Blow" was the word James claimed to have understood (as "explosion" rather than "impact") from the Monteagle letter, when he alone "did upon the instant interpret and apprehend some dark phrases therein" in a manner contrary to any imaginable customary or rational elucidation..$^{50}$ Later Sir Edward Coke alluded to "those dark words of the letter concerning a terrible blow" ${ }^{51}$ Gary Wills observes that in the aftermath of the Plot, words like "train" and "blow" could never have been innocently deployed, any more than "sneak attack" after Pearl Harbour, or "grassy knoll" after the assassination of JFK..$^{52}$ The words would always invoke that unimaginable, unspeakable crime, both terrifying and sublime: 
O horror, horror, horror!

Tongue nor heart cannot conceive, nor name thee. (2.3.56-7) (1) bodies of others can effect a kind of cleansing purgation of the world, sweeping away its corruption, blowing away its power, clearing a space for the incursion of the divine. "Tame your soul, purify it", the 9/11 hijackers were instructed. "Fight them until there is no more Fitnah [unbelief]", says the Qu'ran: "and the worship will all be for Allah (alone in the whole of the world)". (8.39) The Gunpowder Plot was obviously seen as an averted apocalypse from which the kingdom was mercifully delivered: James told Parliament that his kingship had been saved from two trials, a flood of spilled blood and a fire (the Gowrie Conspiracy and the Gunpowder Plot), which could have been "two great and fearful Doomsdays". ${ }^{44}$ By the same token, the hope of destroying "the whole body of the state" at one blow was an aspiration of apocalyptic proportions.

Macbeth is, of course, full of apocalyptic language and symbolism, often generalised but often also specifically eschatological: Duncan's murder is in itself “'the great Doom's image". (2.3.72) The strongest apocalyptic feeling in the play is that of the time growing short, running out: the kingdom is at hand. That which has always been about to come, is suddenly on its way. "The time between you and your marriage in heaven is very short". ${ }^{55}$ Lady Macbeth, on receiving her husband's letter, feels immediately transported "beyond/This ignorant present", and able to feel futurity bursting through the immediate. "I feel now/The future in the instant" (1.5.54-6). Barker says of this 
speech that it betrays an "aspiration which is prepared dynamically to reshape time in a quasi-modernist, if not almost revolutionary apprehension of the present 'instant' as a constellation pregnant, shot through with a desired future" ${ }^{56}$ In his analysis this hope is the embryonic revolutionary content of Macbeth, that messianic hope for change in "the entire order of things" which the play's ultimately legitimist ideology cannot countenance.

But in Macbeth what hope lies beyond the change? Freedom, justice, democracy? Anything that Frances Barker would have wanted to see? No: only death. "When the hour of reality approaches, the zero hour ... wholeheartedly welcome death for the sake of God". ${ }^{57}$ There will be a future, those men must have been assured, in which the dar al Islam covers the whole world, and their actions would contribute to its eventual victory. But the suicide bomber will not see it. No matter: he already has his reward. They were brought to believe, and presumably must have believed, that they would step off tarmac and into heaven. "Afterwards begins the happy life". This is what it really means to "jump the life to come", to "jump the gap between word and deed", ${ }^{8}$ to accomplish with one catastrophic action the immediate collapsing of the boundaries between present and future, between this world and the next. There are only two places in which such a sublime transfiguration is conceivable: one is in suicidal terrorism like $9 / 11$, and the other is in art. And there is an "unconfessable complicity" between the two.

We can see this complicity, as Terry Eagleton has recently reminded us, in Conrad's novel The Secret Agent, "the first suicide-bomber novel of English literature". ${ }^{59}$ Conrad depicts a corrupt world which he himself would like to see swept away: so he cannot avoid an imaginative sympathy with his own creation the Professor. "What's wanted" states the Anarchist suicide-bomber, "is a clean sweep and a clear start of a new conception of life". ${ }^{60}$ Eagleton points out that this is also "the familiar cry of the avantgardist who rather than submit to the messiness of history and material process seeks to leap at a bound from present to future, actual to desirable, finite to infinite". ${ }^{61}$ To feel, one might say, 'the future in the instant' of self-destructive cataclysm.

Karlheinz Stockhausen provoked outrage when he confounded art and reality over 9/11, calling it "the greatest work of art imaginable for the whole cosmos". ${ }^{62} 9 / 11$ created on a grand scale "the leap out of security, out of what is usually taken for granted, out of life, that sometimes happens to a small extent in art":

Minds achieving something in an act that we couldn't even dream of in music, people rehearsing like mad for 10 years, preparing fanatically for a concert, and then dying, just imagine what happened there. You have people who are that focused on a performance and then 5,000 people are dispatched to the afterlife, in a single moment. I couldn't do that. By comparison, we composers are nothing. Artists, too, sometimes try to go beyond the limits of what is feasible and conceivable, so that we wake up, so that we open ourselves to another world. ${ }^{63}$

The fortuitous correspondences with the vocabulary of Macbeth are eerily repetitive: "act", "dream", "dispatched", "wake". Attempting later to distance himself from his own words ("It's a crime because those involved didn't consent. They didn't come to the 'concert'."), Stockhausen came even closer to the language of terrorism in Macbeth: "What happened spiritually, this jump out of security, out of the self-evident, this sometimes also happens in art ... or it is worthless" (my emphasis) ${ }^{64}$. Stockhausen and Macbeth share the same word, "jump" (Sprung), and bring together in a common vocabulary the shared fantasies of aesthetic transcendence and suicidal martyrdom. 
28 Macbeth lives beyond the moment of his transcendence into a world devoid of meaning, where there is "nothing serious in mortality" (II.iii.84). Asked if the terrorism of Al-Qaida could be identified as a "a quintessential expression of founding violence", the kind of revolutionary violence that lies at the root of every state, Derrida said that such terrorist violence differs from political violence in that its actions "open onto no future", it leaves "nothing good to be hoped for". ${ }^{65}$ So in Macbeth the millennial rapture of feeling the future in the instant is replaced by the weary fatalism of "tomorrow and tomorrow and tomorrow". Everything can be done tomorrow: tomorrow, perhaps, they will finally feel "safe". Notwithstanding, they remain stranded "here upon this bank and shoal of time", where tomorrow never comes, since there is "nothing good to be hoped for".

We see, then, why Shakespeare is such an interesting subject for reflections on terrorism. As a man, if Richard Wilson, Stephen Greenblatt ${ }^{66}$ and others are right in their speculations about Shakespeare's crypto-Catholicism, Shakespeare could have made the choice to enlist under the banner of religious martyrdom. Perhaps that's why he was able to dramatise those forbidden desires, that secret jubilation, that messianic hope that seems so much clearer about the coming terrors (which as we know are within our power to bring about), than about the kingdom to come. But if Catholic martyrdom was an option for Shakespeare, it's one he didn't take. So simultaneously he was able to depict the reality of that nothingness that would inevitably follow on such violent destruction, and to compare it honestly, if ruefully, with the imperfections of the status quo. Better Malcolm than Macbeth, Shakespeare probably would have said; better James I than Thomas Percy. Better even Bush than bin Laden.

Despite their family resemblances, art and terrorism are not analogous but diametrically opposed to one another. The cynicism of Baudrillard's "terrorist imagination", or the feverish excitement of Stockhausen's catastrophic "concert", give access to an element of the truth about 9/11. Tragedy began with the violence of Dionysian ecstasy, and with sacrifice. But the violence was ritualised and framed, and the human sacrifices, Pentheus or Oedipus, were slaughtered only in imitation. "Philosophical and artistic works", says Kearney,

are [...] capable of furnishing some extra, because indirect, insights into the enigma of horror. For both proffer an unnatural perspective on things - by virtue of style, genre and language. ${ }^{67}$

31 I agree that terrorism speaks, communicates meaning, and conveys a message. But I want to insist that as an ethical and spiritual action it speaks only of itself, exhausts itself in its utterance. In defining terrorism, in Jurgensmeyer's words, as "the public performance of violent power" ${ }^{68}$, we should also appreciate that the meaning of a performance is unique and integral, and can't be assimilated to something outside or beyond it. To say that terrorism is propaganda by deed is not the same as saying that the violence is merely a proxy for the propaganda, or that the propaganda can somehow disown the deed, that something irrational can convert itself into something rational. To return for a moment to the death of Riccio. A drunken husband butchers his wife's lover before her eyes; surely one of the worst cases of domestic violence on record. A gang of Protestant men, fired up by John Knox's sermons against the monstrous regiment of women, show the queen how things should be done in a man's world. The message is sectarian hatred and masculine violence; and the medium is the message. There is no way this crime can be re-written as an exemplification of republican virtue. Terrorism speaks: but its words are daggers; its grammar cruelty, its 
syntax innocent blood. In ISIS we have a terrorist organisation that collapses all such intellectual distinctions, and acknowledges no difference between war and peace, combatant and civilian. ISIS has no intelligible 'secular and strategic' goal, like ridding what they see as Muslim lands of foreign troops. Its use of terror is not tactical, it is constitutive. Does ISIS use terror to found an Islamic state? Or does it want an Islamic state in order to freely deploy terror?

I can only reiterate my reading of Macbeth in "Shakespeare and Terror": the assassin is driven by fear; and obsessively seeks, with an apocalyptic urgency, a "cleansing purgation" of the world from that which he fears most, the power of others. Yes of course Macbeth wants to found a dynasty, and can't bear the thought of Banquo's seed succeeding him. But what he wants to see in that vision of the future is his own lineage, a succession of little Macbeths stretching out to the crack of doom. But this is not a political agenda: it's a rejection of all politics to make room for an infinite extension of the self. "For mine own good/All causes must give way" (3.4.141-2).

Setting the language of Islamic terrorism (such as the 9/11 Spiritual Manual) ${ }^{69}$ alongside testimony from the Gunpowder Plotters and Shakespeare's Macbeth, we can clearly see a commonality of discourse. "Fear is a great form of worship" says the 9/11 Manual, "and the only one worthy of it is God". At his trial Fawkes bore a "stern look, as if he would frighten death with a frown". ${ }^{70}$ "Why do I yield to that suggestion", asks Macbeth, "whose horrid image doth unfix my hair/And make my seated heart knock at my ribs/Against the use of nature?" (1.3.138-41)

"Fight them until there is no more Fitnah" says the Quran "and the worship will all be for Allah" (8.39). The Gunpowder Plotters aimed to "purge the realm of perfidious heresy". ${ }^{71}$ "Scour these English hence", says Macbeth (5.3.58). We will never understand contemporary terrorists, as no less an authority than Justin Welby, Archbishop of Canterbury, speaking in Paris, recently stated, unless we understand the apocalyptic religion they take literally, and seek to put into practice..$^{72}$ All three of these historical examples - the Gunpowder Plot, Macbeth, 9/11 - are religious events fuelled by apocalyptic visions. But our interpretative methods are not religious. We eschew doctrine and despise dogma. We think there is always another side to the argument; a message beyond the violence; a meaning to disambiguate. But an ISIS beheading video does not require any disambiguation. It means exactly what it says, and says exactly what it means.

Terrorism is evil. Terry Eagleton identifies its root as "the death drive", which

is implacable, vindictive and bottomlessly malevolent, rejoicing in the sight of gouged eye sockets and the bleeding stumps of limbs. It does not simply endorse such destruction, but actively revels in it. It sucks life from death, growing fat on human carnage. ... Those who actively pledge themselves to this force commit deeds which can genuinely be described as evil. ${ }^{73}$

Evil. And let me also reiterate that literature has something of value to say about these matters, alongside religion and philosophy. When the real Frances Tresham asked Catesby if participation in the Plot was "damnable", Catesby insisted it was not. The real 9/11 hijackers were taught to believe they would immediately enter Paradise, to be rewarded for their atrocity: "Afterwards begins the happy life". Each systematically falsifies his own faith. The fictional Macbeth, infused with Shakespeare's Protestant Christianity, knows that he is irrevocably damned: "I have given mine eternal jewel" he says, "to the common enemy of man"; and he lives out his life in torments of 
conscience, "tortures of the mind". Macbeth is emphatically not jihad, though he commits an act of terrorism. He identifies himself as "that man of sin, even the son of perdition" from 2 Thessalonians, the "adversary", who "exalteth himself against all that is called God, or that is worshipped: so that he doth sit as God in the Temple of God, showing himself that he is God" (2 Thess. 3-4).

Blood will have blood.

Stones have been known to move, and trees to speak.

Augurs and understood relations have ... brought forth

The secret'st man of blood. (3.4.128-133)

Shakespeare's great achievement is to reveal to us the 'enigma of horror', ${ }^{74}$ that 'mystery of iniquity' that King James accurately identified as lying behind, and within, all terrorism.

\section{NOTES}

1. Robert Appelbaum, “Shakespeare and Terrorism”, Criticism, 57.1 (Winter 2015), p. 23-45, p. 26.

2. Ibid.

3. Ibid.

4. Martha Crenshaw, 'The Logic of Terrorism: Terrorist Behaviour as a Product of Strategic Choice', in Origins of Terrorism: Psychologies, Ideologies, Theologies, States of Mind, ed. Walter Reich (Washington, DC: Woodrow Wilson Centre Press, 1998), p. 7-24.

5. Jacques Derrida called 9/11 'an unspeakable crime' (Jacques Derrida quoted in Giovanni Borradori, Philosophy in a Time of Terror: Dialogues with Jurgen Habermas and Jacques Derrida [University of Chicago Press, 2003], p. 167; and Edward Coke defined the Gunpowder Plot as 'sine nomine' (Edward Coke, cited in A True and Perfect Relation of the Whole Proceedings Against the Last Most Barbarous Traitors, Garnet a Jesuit, and his Confederates, ed. Henry Garnet [London 1606], sig. D3v2). See below for further examples.

6. Appelbaum, op. cit., p. 23-25

7. Appelbaum, op. cit., p. 24

8. Ibid.

9. In his book Terrorism Before the Letter: Mythography and Political Violence in England, Scotland and France 1559-1642 (Oxford: Oxford University Press, 2015), he argues that it never can be: "terrorist violence never can [succeed]. It cannot control its own aftermath", p. 224.

10. Appelbaum, op. cit., p. 28.

11. Appelbaum, op. cit., p. 29.

12. Edward Coke, cited in A True and Perfect Relation of the Whole Proceedings Against the Last Most Barbarous Traitors, Garnet a Jesuit, and his Confederates, ed. Henry Garnet (London 1606), sig. D3v2.

13. William Barlowe, Sermon Preached at Powles Crosse, the Tenth Day of November Being the Next Sunday After the Discoverie of this Late Horrible Treason (London, 1606), sig. C2v.

14. From the Second Epistle to the Thessalonians. 2.7.

15. Graham Holderness and Bryan Loughrey, "Shakespeare and Terror", in Shakespeare After 9/11: How a Social Trauma Reshapes Interpretation, edited by Matthew Biberman and Julia Reinhardt Lupton (Lewiston, NY: Edward Mellen, 2011), p. 23-56.

16. Holderness, op. cit., p. 423. 
17. Appelbaum, op. cit., p. 43.

18. Holderness, op. cit., p. 44.

19. Appelbaum, op. cit., p. 44.

20. Appelbaum, op. cit., p. 99.

21. Ibid.

22. Coke, op. cit., sig. D3v2.

23. Mark Jurgensmeyer, 'Terror Mandated by God', Terrorism and Political Violence, 9.2 (Summer 1997), p. 17.

24. Peter C. Herman, '"A deed without a name": Macbeth, the Gunpowder Plot, and terrorism', Journal for Cultural Research, 18.2 (2014), p. 116.

25. Barlowe, op. cit., sig. C4r.

26. Coke, op. cit., sig. D3v.

27. James I quoted in Political Writings, edited by J. Sommerville (Cambridge: Cambridge University Press, 1994), p. 149.

28. Derrida quoted in Borradori (2003), p.167.

29. Kristian Versluys, Out of the blue: September 11 and the novel (NY: Columbia University Press, 2009), p. 1.

30. Appelbaum, op. cit., p. 26.

31. Herman, op. cit., p. 127.

32. Ibid.

33. Terry Eagleton, Holy Terror (Oxford: Oxford University Press, 2005), p. 17.

34. Alan Sinfield, Faultlines (Berkely: University of California Press, 1992), p. 94.

35. Ibid.

36. Slavoj Zizek, Violence (London: Profile Books, 2009), p. 2.

37. Francis Barker, The Culture of Violence: tragedy and history (Manchester: Manchester University Press, 1993), p. 65-66.

38. Barker, op. cit., p. 64.

39. Quotations from Macbeth, ed. A.R. Braunmuller (Cambridge: Cambridge University Press, 1997).

40. Christopher Pye, 'The Sovereign, the Theatre, and the Kingdome of Darknesse: Hobbes and the Spectacle of Power', in Stephen Greenblatt, ed., Representing the English Renaissance (Berkeley: University of California Press, 1988), p. 299. 'The authoritarian preserves a secret compact with the anarchist'. Eagleton, Holy Terror (2005), p. 9.

41. Barker, op. cit., p. 59.

42. Barker, op. cit., p. 60.

43. Barker, op. cit., p. 66.

44. Barker, op. cit., p. 70.

45. Stephen Greenblatt, "Invisible bullets": Renaissance authority and its subversion', in Alan Sinfield and Jonathan Dollimore, eds., Political Shakespeare: new essays in cultural materialism (Manchester: Manchester University Press, 1985), p. 33.

46. Steven Mullaney, The Place of the Stage: licence, play and power in Renaissance England (Chicago: Chicago University Press, 1988), p. 126.

47. Jonathan Goldberg, 'Macbeth and Source', in Jean E. Howard and Marion F. O'Connor, eds., Shakespeare Reproduced: the text in history and ideology (London and NY: Methuen, 1987), p. 249.

48. Leonard Tennenhouse, Power on Display: the Politics of Shakespeare's Genres (London: Methuen, 1986), p. 15.

49. Richard Wilson, "Blood will have Blood": regime change in Macbeth', Deutsche-ShakespeareGesellschaft-West Jahrbuch, Vol. 143 (2007), p. 16.

50. Quoted in Gary Wills, Witches and Jesuits: Shakespeare's 'Macbeth' (Oxford: Oxford University Press, 1995), p. 19. 
51. Wills, Witches and Jesuits (1995), p. 123.

52. Quoted Wills, op. cit., p. 27.

53. Quoted Wills, op. cit., p. 21.

54. Quoted Wills, op. cit., p. 19.

55. "Last Words of a Terrorist." The Guardian, 30 September 2001. Available at [http:// www.guardian.co.uk/world/2001/sep/30/terrorism.september113]. Accessed 30 December 2016. The document has been published in H.G. Kippenberg and Tilman Seidensticker, The 9/11 Handbook: Arabic Text, Annotated Translation and Interpretation of the Attacker's Spiritual Manual (London: Equinox, 2006). See also Hans G. Kippenberg, "'Consider that it is a Raid on the Path of God': The Spiritual Manual of the Attackers of 9/11", Numen, Vol. 52, No. 1 (2005), p. 29-58.

56. Barker, op. cit., p. 63.

57. "Last Words of a Terrorist" (2001).

58. Frank Lentricchia and Jody McAuliffe, Crimes of Art and Terror (Chicago: University of Chicago Press, 2003), p. 8.

59. Eagleton, Holy Terror (2005), p. 121.

60. Quoted Eagleton, Holy Terror (2005), p. 123.

61. Ibid.

62. Quoted in Julia Spinola, 'Monstrous Art', Frankfurter Allgemeine Zeitung, 25 September 2001.

63. Stockhausen, quoted Lentricchia and McAuliffe, Crimes of Art and Terror (2003), p. 9-10.

64. Ibid.

65. Derrida quoted in Borradori, Philosophy in a Time of Terror (2003), pp. 167, 113.

66. Stephen Greenblatt, Will in the World: how Shakespeare became Shakespeare (London: Jonathan Cape, 2004), pp. 108-110.

67. Richard Kearney, Strangers, Gods and Monsters: interpreting otherness (London: Routledge, 2002), p. 134.

68. Jurgensmeyer, op. cit., p. 17.

69. "Last Words of a Terrorist" (2001).

70. Antonia Fraser, Faith and Treason: the story of the Gunpowder Plot (London: Anchor Books, 1997), p. 219.

71. See H.F. Browne (ed.), Calendar of State Papers: Venice (London: Public Record Office, 1900), vol. 10, p. 289.

72. 'Bishop Bashes Jihadis'. The Sun, 19 November 2016. Available at [https://www.thesun.co.uk/ news/uknews/2219097/archbishop-of-canterbury-justin-welby-slams-isis-apologists-who-saygroup-are-not-islamic-as-he-demands-religious-leaders-take-responsibility-for-terror-fanaticscrimes] [Accessed 30 December 2016].

73. Eagleton, op. cit., p. 18.

74. Kearney (2002), p. 134.

\section{RÉSUMÉS}

Cet article propose une relecture critique du travail de Robert Appelbaum sur Shakespeare et le terrorisme, et plus particulièrement de ses réflexions sur Macbeth et la Conspiration des poudres. Le présent texte vise à démontrer que le terrorisme tel qu'il s'est incarné dans la Conspiration des poudres et le 11 septembre est peut-être en réalité, en dépit de ses motifs affichés, une forme 
de nihilisme essentiellement destructrice et n'offrant, pour citer Derrida, "rien de bon à attendre". Ce que le Macbeth de Shakespeare parvient à dévoiler, par le truchement des langages poétique et religieux, c'est le "mystère de l'iniquité" (2 Thessaloniciens 2:7) qui sous-tend toute forme de terrorisme.

This article offers a critique of Robert Appelbaum's work on Shakespeare and terrorism, particularly his reflections on Macbeth and the Gunpowder Plot. It argues that terrorism such as that exemplified by the Gunpowder Plot and 9/11 may, whatever their ostensible motives, be in reality nihilistic, merely destructive and offering (in Derrida's words) "nothing good to be hoped for". The achievement of Shakespeare's Macbeth is to expose, via the languages of poetry and religion, the 'mystery of iniquity' (2 Thess. 2.7) that lies behind all terrorism.

\section{INDEX}

Keywords : Robert Appelbaum, Gunpowder Plot, Macbeth, nihilism, terrorism, 9/11

Mots-clés : Robert Appelbaum, Conspiration des poudres, Macbeth, nihilisme, terrorisme, 11 septembre

\section{AUTEUR}

\section{GRAHAM HOLDERNESS}

Hertfordshire University 